Spontaneous cholecystocutaneous abscess が合併した遊走胆囊の 1 例

$$
\text { 太田智行 濱 砂一莫 }
$$

87歳, 女性, 右下腹部の発赤を伴う膨隆を他院で指摘され, 精查加療目的で当院へ般 送された。超音波検査およびCT 検查では右下腹部腹腔内に結石を有する cystic lesion とこれに連続寸る皮下膿湟の存在が示唆された。緊急手術を行ったところ, 腹腔内病変

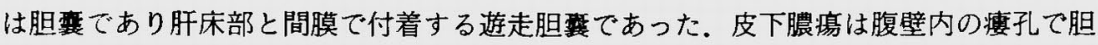
衰と連続しており spontaneous cholecystocutaneous abscess（自発性胆囊皮凰膿場）と

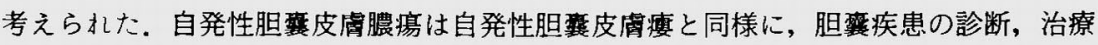
の発達した現在では稀である。検索しえた範囲で，遊走胆襄に合併した症例はこれが最 初の報告である。

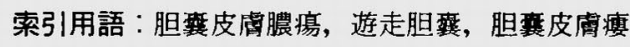

\section{緒 言}

Spontaneous cholecystocutaneous abscess or fistula (自発性胆亯皮膚膿瘍または自発性胆雚皮膚瘦, 以 下 spontaneous CCA-F) "'は17世紀から知られていた 胆壤疾患の合併症であり，胆軎穿孔に引き続き生じる 皮下膿瘍および皮膚瘦である。これらは特に胆石症診 療の進歩により，現在では稀になったと考えられてい

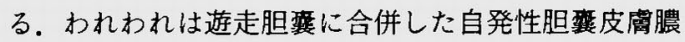
湯を経験した。検索した限りにおいて過去に報告はな く自験例が最初の報告である。

$$
\text { 症例 }
$$

患者: 87歳, 女性.

主訴：右下腹部皮下腫瘤.

既往歴：痴呆，うっ血性心不全，胆石を指摘されて いた。

現病歴：うっ血性心不全増悪で他院に入院中, 2002 年 3 月 23 日より $40^{\circ} \mathrm{C}$ 台の発熱あり. 3 月26日には右下 腹部に発赤を伴う腫脹出現, 精查加療目的で当院外科 に搬送された。

入院時現症：血圧 $83 / 56 \mathrm{mmHg}$, 脈拍 $73 /$ 分, 体 温 $37.4^{\circ} \mathrm{C}$, 眼瞼結膜に賓血なし, 眼球結膜に軽度黄疸あ り。右下腹部に圧痛を伴う手拳大, 軟の膨隆あり。膨

2003年10月 1 日受付 2001年 1 月14日採用 〈所属施設住所〉

厂270-0174 流山市下花輪409
隆およびその周囲に発赤，熱感を認めた（図 1 ).

検査所見 (表 1 ): 血液生化学検査では白血球数 $12,600 / \mu 1, \mathrm{CRP} 21.42 \mathrm{mg} / \mathrm{dl}$ と炎症反応の上昇と血清 ビリルビン値の軽度上昇を認めた。

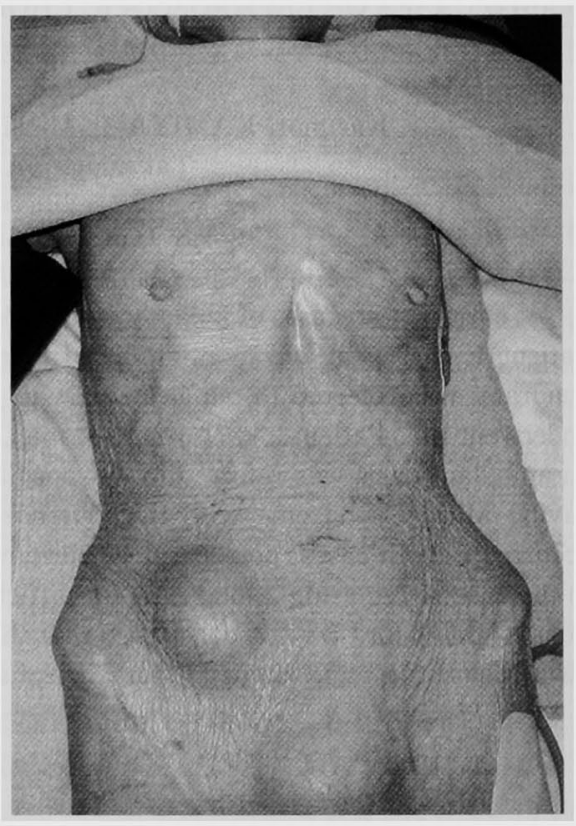

図 1 入院時現症：右下腹部に発赤を伴った手 拳大の膨隆が認められる. 
表 1 入院時検査結果

\begin{tabular}{lrlr}
\hline $\mathrm{WBC}$ & $12.600 / \mu \mathrm{l}$ & $\mathrm{TP}$ & $5.9 \mathrm{~g} / \mathrm{dl}$ \\
$\mathrm{RBC}$ & 288 万 $/ \mu \mathrm{l}$ & $\mathrm{GOT}$ & $16 \mathrm{U} / 1$ \\
$\mathrm{Hb}$ & $8.6 \mathrm{~g} / \mathrm{dl}$ & $\mathrm{GPT}$ & $11 \mathrm{U} / 1$ \\
$\mathrm{Hct}$ & $25^{\circ}$, & $\mathrm{LDH}$ & $268 \mathrm{U} / 1$ \\
$\mathrm{PLT}$ & 24.6 万 $/ \mu \mathrm{l}$ & $\mathrm{CPK}$ & $22 \mathrm{IU} / 1$ \\
& & $\mathrm{~T} \cdot \mathrm{Bil}$ & $2.5 \mathrm{mg} / \mathrm{dl}$ \\
$\mathrm{Na}$ & $134.9 \mathrm{mEq} / \mathrm{l}$ & $\mathrm{BUN}$ & $32.8 \mathrm{mg} / \mathrm{dl}$ \\
$\mathrm{K}$ & $3.8 \mathrm{mEq} / 1$ & $\mathrm{Cr}$ & $0.94 \mathrm{mg} / \mathrm{dl}$ \\
$\mathrm{Cl}$ & $101.4 \mathrm{mEq} / \mathrm{l}$ & $\mathrm{CRP}$ & $21.4 \mathrm{mg} / \mathrm{dl}$ \\
\hline
\end{tabular}

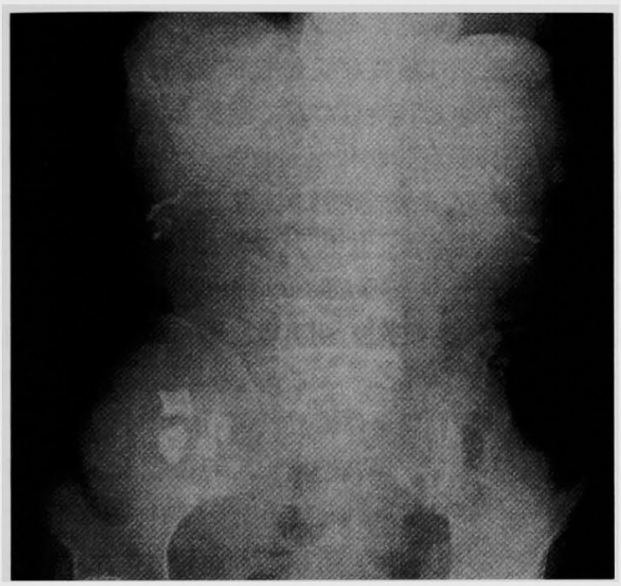

図 2 腹部単純 $\mathrm{X}$ 線写真 : 右下腹部に数個の結石像 がみられる。

腹部単純 $\mathrm{X}$ 線写真（図 2 ）：右下腹部に石灰化を伴 った複数の結石像あり.

腹部超音波検查 (図 3 )：右下腹部皮下に腹腔内只 連続する cystic lesion がみられた，同病変の樑部，腹 腔側には音響陰影を伴った strong echoがみられ結石 像と判断した。

腹部 CT 検査 (図 4)：右下腹部皮下から腹腔内に連 続し, 辺縁部が造影される cystic lesion が存在する. 同病変の深部, 腹腔内には数個の結石像が認められる. 胆石を指摘されていたが胆聚摘出術は行われておら ず,腹胯内の結石を有した cystic lesion は通常の部位 から偏位して炎症を有した胆鋒であり，これが皮下膿 瘍を形成したものと考えられた，同日緊急手術を施行 した.

手術所見(図 5)：膨隆部に皮凰切開を加えると膿が

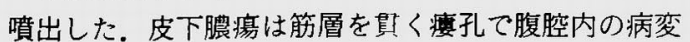
と交通しており，そこには結石が認められた。腹腔内

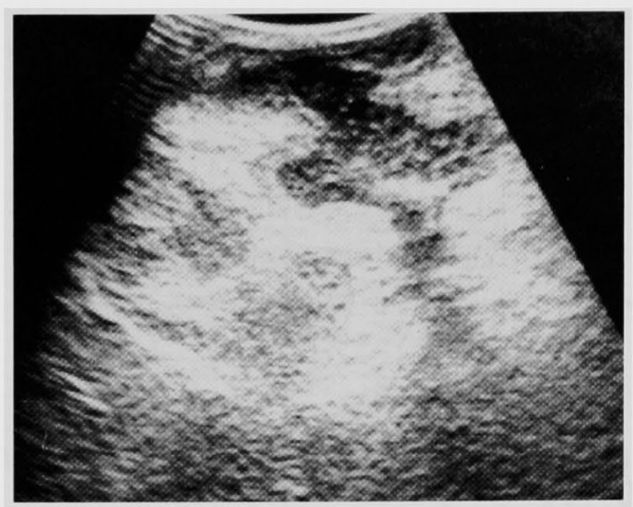

図 3 腹部超音波検査：深部 cystic lesionには音響 陰影を伴った strong echoがみられ結石像と思わ れた。皮下の病変とは連続している。

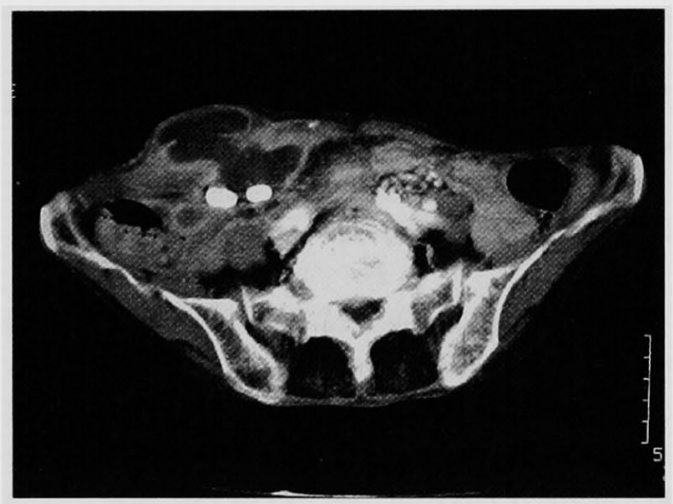

図4 腹部 ( $\mathrm{T}$ 検查：辺縁部がよく造影される病変が腹 腔内および皮下にみられ，これらは連続している．腹腔 内病変には石灰化を有する数個の結石像がられる。

病変と肝臓下面, 胆咅窩の間には間模榚の構造物が存 在し，その中には総胆管から腹腔内病变まで連なる索 状物がみられ胆篦と思われた。この時点で腹腔内病 変は胆苝このものであると判断し，これに痣着した消 化管を剝離した徯, 筋層瘦孔部の周囲組織と一塊にし て摘出した。総胆管に Tチューブを挿入し胆道造影検 查を施行，総胆管結石のないことを確認した。

細菌培養検查：膿汁から Klebsiella pneumoniae を 娭出.

病理組織学的所見：胆聚壁は厚く一樣に線維化した 組織であった。悪性所見は認められなかった。

診断：腹腔内の病変は胆石を有する遊走胆慗 (Gross A ${ }^{2)}$ であり繰り返し炎症を起していたものよ 


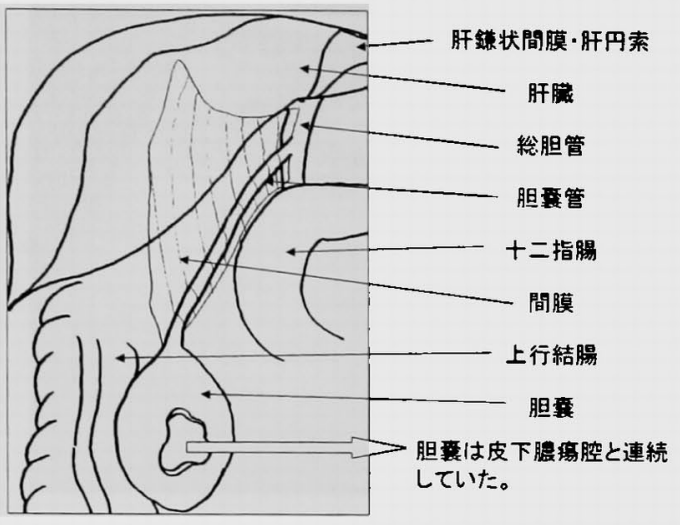

図 万手術所見模式図 : 総胆管から肝下面胆西窝にわたっ て間膜が付着しており腹腔内病変まで連続していょっこ の中には総胆管から腹腔内病变へ連なる索状物がみられ 胆政管と思わ机た。

思われた。皮下膿瘍は胆囊炎に続発した自発性胆襄皮 凰膿惶と考えられた。

術後経過：不穏などみられたが鎮静剤で落ち着き， 術後経過良好であった。

\section{考 察}

spontaneous C CA-F は1670年 Thilesusによって最 初に報告された胆管疾患の合併症である。現在これら の疾患は稀こあるが，之れは超音波検㚗による胆石症 骖断の迅速化, 広域抗生剂の導入や早期外科治療のた せ上考えウれている゙!。

\section{没学・発生部位}

50 70歳代の女性に多い"，発生部位としこは右上

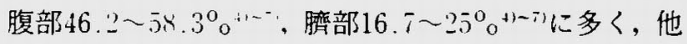

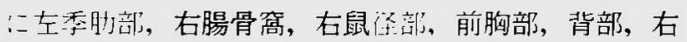
殿部などの報告がある、臍部に多いのは肝鎌状間膜お よび肝円索を介して腿部に炎症が及っ゙ためと考えられ ている゙!

成因・病態

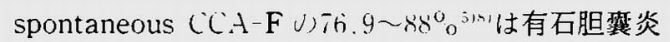
から生じると言われている，胆石の嵌頓で胆整内圧が 九進, 胆露穿孔をきたし, それに続発して生じる皮下 膿瘍または皮虞瘦である。穿孔部は胆懐底部に多いか， これは解剖学的に最も血流の乏しい部位のためと考え られている他。他に少数ながら胆要癌6101-14)や無石胆

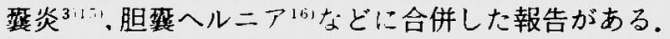
胆萑癌の症例では癌が直接腹壁に浸潤して瘦孔を形成 したと考えられるものもあるい1.また,本症例のように
知呆症合併例などでは，症状がわかりにくいことが病 状を進行させる要因であることが指摘されている 診断

右上腹部の皮下膿瘍や皮膚瘦があれば spontaneous C C A - F を疑ってみるべきであう。瘦孔から胆汁や胆 石が排出するようであれば診断は容易であろう。最初 から皮栭瘦のある場台はそのまま，ない場合は切開ま たは穿刺排膿の後に瘦孔造影がなされ診断が確定した

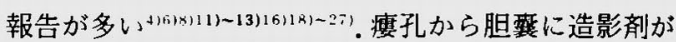
流入することで確定診断が得ら扎る。また瘦孔の走行 や内瘦の有無も確認することができ，適切な手術を行 う上で瘦孔造影は重要な検査である。

超音波検査や CT 検査などで胆粠と皮下膿瘍の連続 性が確認され確定診断に至った報告やっ，術前に胆襄

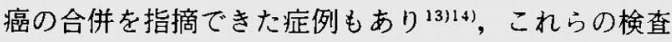
も治療方針を決めろ上で重要である。

治療

抗生物質投与, 切開ドレナージ術, そして胆蝇摘出 術および瘦孔切除術が挙げられる。切開ドレナージ術 は全身状態の悪い患者にも施行可能で，炎症のコント ロールを容易にし，瘦孔造影が可能になる点で有用で ある.1950年代までに限定すると，本邦の症例集計で は切開ドレナージ術のみで治痊した報告が半数以上を 占めている ${ }^{14)}$.しかし, 最近の報告例ではドレ+ージ術

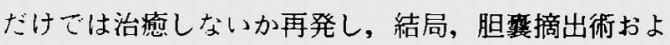
び瘦孔切除術が必要となった症例が多い6(8)12120127). 胆 石が残存する場合は再発の可能性があり, 積極的に胆 䗸摘出術および摟孔切除術を行うべきである.

胆褧癌合併率は $19.4^{\circ} \circ$ 。(6/36例) ${ }^{6)}$ と高率で, また 外胆汁瘦を長期に有していた患者の瘦孔に腺癌が発生 した報告がある゙. 癌合併の点からも保存的治療だけ に頼ることは避けるべきである.

遊走胆雚は胆籆捻転症をきたすことで知られてい

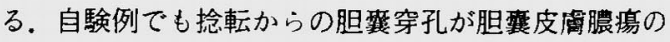
原因となった可能性を考えたか，これを確認すること はできなかった。

\section{おわりに}

遊走胆露に自発性胆雚皮膚膿貆が合併した 1 例を経 験した．膨隆が右下腹部であったため診断に苦慮した オ，病歴と画像所見から病態を把握することが可能て あった，一期的に胆裂摘出術および膿瘍部切除術を施 行したか，術後経過は良好であった。 


\section{文献}

1) Kumar SS: Laparoscopic managemant of a cholecystocutaneous abscess. Am Surg 64: 1192-1194, 1998

2) Gross RE: Congential anomalies of the gallbladder. A review of 148 cases with report of double gallbladder. Arch Surg 32:131-162, 1936

3) Chang SS, Lu CL, Pan CC, et al : Spontaneous Cholecystocutaneous Fistula Presenting With a Cellulitis and Portal Vein Thrombosis. J Clin Gastroenterol 34:99-100, 2002

4) Henry CL, Orr TG: Spontaneous external biliary fistulas. Surgery $26: 641-646,1949$

5) 安田慎治, 堀田敦夫, 深井麦俊他：自発性外胆覆 漊の1治呀例. 日臨外医会誌 $47: 793-799,1986$

6）紫藤和久，遠藤則之，白倉外茂夫他：胆裂制部癌 に合併した自発性胆整皮盧瘦の 1 例. 日消外会誌 $30: 2297-2301, \quad 1997$

7) Tuna IC, Maizel S, O'Connor M, et al : Simultaneous cholecystocutaneous and cholecystoduodenal fistulae. Minn Med $69: 77-78,1986$

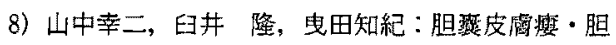
酸結腸瘦を合併した胆石症の1例。日䠦外会誌 $61: 771-774,2000$

9) Roslyn J. Busuttil RW : Perforation of the gallbladder : a frequently mismanaged condition. Am J Surg 137 : 307-312, 1979

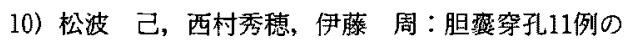
治験。日臨外医会誌 $40 ： 507,1979$

11）黑須 靖：自発性腹壁瘎孔を形成せる胆石症（胆 瘦癌) の1例. 臨外 $13: 55-57,1958$

12) Hoffman L, Beaton $H$, Wantz $G$ : Spontaneous cholecystocutaneous fistula: a complication of neglected biliary tract disease. J Am Geriatr Soc $30: 632-634,1982$

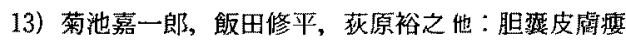
と胆要肝管瘦を同時に認めた胆石合併胆㱸癌の 1 例. 胆道 $9: 260-265,1995$

14）関川浩司, 渡辺岩雄, 川口吉洋他：自発性外胆露

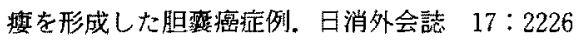

$-2229,1984$

15) Birch BR, Cox SJ : Spontaneous external biliar * y fistula uncomplicated by gallstones. Postgrad Med J 67:391-392, 1991

16) Carragher AM, Jackson PR, Panesar KJ : Subcutaneous herniation of gall-bladder with spontaneous cholecystocutaneous fistula. Clin Radiol 12 : 283-284, 1990

17) Gifford J, Saltzstein SL, Bavone RM : Adenocarcinoma occurring in association with a chronic sinus tract and biliary fistula. Cancer $47: 2093-2097,1981$

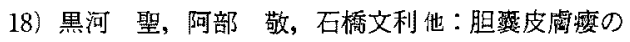
1 例。釧路病医誌 $6: 122-127,1994$

19) 中北信昭, 西村博行, 横田和彦他: 特発性胆露皮 简嚓の 1 手術治験例.消外 9：1435-1438, 1986

20) Ulreich $S$, Henken EM, Levinson ED : Imaging in the diagnosis of cholecystocutaneous fistulae. J Can Assoc Radiol 34:39-41, 1983

21）舟生一義, 栗原平助, 中村慶彦：腹壁に自潰した 與味する䏣石症の1手術治験例。日大医誌 22 ： $582-586,1963$

22) Hakaim AG, Vogt DP : Spontaneous cholecystocutaneous fistulas. Cleve Clin Q $53: 363-$ 365,1986

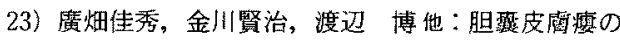
1 症例。肝・胆 - 猝 $26: 1011-1015,1993$

24) Andley M, Biswas RS. Ashok S, et al: Spontaneous cholecystocutaneous fistula secondary to calculous cholecystitis. Am J Gastroenterol $91: 1656-1657,1996$

25) Nicholson T, Born MW, Garber E: Spontaneous cholecystocutaneous fistula presenting in the gluteal region. J Clin Gastroenterol $28: 276$ $-277,1999$

26) Gibson TC, Howat JM: Cholecystocutaneous fistula. Br J Clin Pract 41:980-982, 1987

27) Abril A, Ulfohn A:Spontaneous cholecystocutaneous fistula. South Med J 77 : 11921193,1984 


\title{
A CASE OF FLOATING GALLBLADDER COMPLICATED WITH \\ CHOLECYSTOCUTANEOUS ABSCESS
}

\author{
Tomoyuki OHTA, Kazumitsu HAMASUNA and Giichiro OHNO \\ Department of Surgery, Tokatsu Hospital
}

An 87-year-old woman with a history of cholelithiasis and senile dementia suffering swelling with fever and redness in the right lower quadrant (RLQ) was found in abdominal US and CT to have a possible subcutaneous abscess in the RLQ and an intraperitoneal cystic lesion with calcified stones connected to the subcutaneous lesion. In emergency surgery, the intraperitoneal lesion proved to a chronic inflamed floating gall bladder and the subcutaneous lesion was a spontaneous cholecystocutaneous abscess. Similar to spontaneous cholecystocutaneous fistulas, spontaneous cholecystocutaneous abscess is rare. We report the first case, to our knowledge, of floating gall bladder complicated with spontaneous cholecystocutaneous abscess. 